AperTO - Archivio Istituzionale Open Access dell'Università di Torino

\title{
Implementation of the Duty of Care by the World Bank
}

\section{This is the author's manuscript}

Original Citation:

\section{Availability:}

This version is available http://hdl.handle.net/2318/1678287

since 2018-10-21T12:57:36Z

Publisher:

Asser Press, Springer

Published version:

DOI:10.1007/978-94-6265-258-3

Terms of use:

Open Access

Anyone can freely access the full text of works made available as "Open Access". Works made available under a Creative Commons license can be used according to the terms and conditions of said license. Use of all other works requires consent of the right holder (author or publisher) if not exempted from copyright protection by the applicable law. 


\title{
Chapter 12
}

\section{Implementation of the Duty of Care by the World Bank}

\author{
Annamaria Viterbo*
}

\begin{abstract}
The objective of this Chapter is to assess how the organizations of the World Bank Group implement the Duty of Care owed to personnel who are performing official tasks, or on assignment, outside the Washington DC headquarters. The first section of this Chapter analyses the WB Group's internal law on rights and obligations of the Bank and its staff, as fashioned by the jurisprudence of the World Bank Administrative Tribunal, and its scope of application. The second section examines in more detail how the various aspects of the Duty of Care obligation are addressed within the WB Group, focusing in particular on: non-discrimination, health and safety of the personnel, information on potential dangers and adequate training, specific challenges and threats, effective medical services after an incident has occurred, and the exercise of functional protection. The final section gives a brief overview of the WB Group's internal administrative procedures established to address personnel's requests and complaints.
\end{abstract}

Keywords: World Bank, Duty of Care, 1983 Principles of employment, Staff Rules, Administrative Manual Statements, World Bank Administrative Tribunal

\section{Table of Contents}

12.1 Introductory remarks

12.2 Legal sources

12.2.1 Internal sources

12.2.2 External sources

12.3 Scope of application

12.3.1 Ratione loci

12.3.2 Ratione personae

12.4 Content of the WB Group's Duty of Care obligations

12.4.1 Non-discrimination

12.4.2 Health and safety of the personnel

12.4.3 Information on potential dangers and adequate training

12.4.4 Specific challenges and threats

12.4.5 Effective medical services after an incident has occurred

12.4.6 Exercise of functional protection

12.5 Administrative procedures

12.6 Conclusions and recommendations

Reference list

List of cases

* Annamaria Viterbo, Associate Professor of International Law at the University of Turin and Collegio Carlo Alberto Law Affiliate, anna.viterbo@unito.it. 


\subsection{Introductory remarks}

At the end of World War II, a rule-based multilateral framework was established to regulate monetary and economic relations among States. In 1944, the United Nations Monetary and Financial Conference was convened in Bretton Woods, New Hampshire, in the United States (US) to negotiate the Articles of Agreement of two International Organisations: the International Monetary Fund (IMF) and the International Bank for Reconstruction and Development (IBRD).

The original mission of the IBRD consisted of fostering economic development in member States, providing assistance for the reconstruction of war-torn Europe and favouring the transition to a peace-time economy. ${ }^{1}$ Shortly after its foundation, though, due to the US bilateral aid programme for Western Europe, the IBRD essentially shifted its focus to providing project financing and adjustment loans to developing countries.

Soon it became clear that the poorest countries could not afford to borrow capital at the almost ordinary market conditions set by the IBRD. To overcome this problem, in 1960 the International Development Association (IDA) was established to provide long-term loans at no interest to poorer countries.

Together the IBRD and the IDA are officially referred to as the 'World Bank' (WB). ${ }^{2}$ The 'World Bank Group' (WB Group) however also comprises three other legally and financially independent International Organizations: the International Finance Corporation (IFC), which was established in 1956 to finance and promote sustainable private sector investments in developing countries; the International Centre for Settlement of Investment Disputes (ICSID), set up in 1966 to provide the institutional and procedural framework for the conciliation and arbitration of disputes between foreign investors and States; and the Multilateral Investment Guarantee Agency (MIGA), created in 1988 with a mandate to promote foreign direct investment in developing countries, offering political risk insurance to investors and lenders.

The IBRD, IDA and IFC are specialised agencies of the United Nations (UN) and, as such, they are members of the UN System Chief Executives Board for Coordination (CEB). ${ }^{3}$

\footnotetext{
${ }^{1}$ On the history of the World Bank see among many: Coffey and Riley 2006; Kapur, Lewis and Webb 1997; Mason and Asher 1973; Shihata 1991.

${ }^{2}$ Darrow 2006; Marshall 2008; Philips 2009.

${ }^{3}$ Its members include the Executive Heads of the UN, 15 specialised agencies (including the World Bank and the IMF), 12 Funds and Programmes created by the UN General Assembly and 3 related Organizations (the WTO, UNOPS and IAEA).
} 
The origins of the CEB date back to 1946, when the ECOSOC requested the UN Secretary General to 'establish a standing committee of administrative officers of the specialized agencies' 4 to improve coordination within the UN System.

Nowadays, the CEB is the main UN inter-agency instrument for coordination and cooperation. In order to carry out effectively its mandate, three high-level committees have been created. Among these, the High-Level Committee on Management (HLCM) is mandated to promote staff safety and security and to administer the UN Security Management System (UNSMS). ${ }^{5}$

It has to be observed though that, while the Organizations of the WB Group participate in the CEB and the UNSMS, ${ }^{6}$ they do not belong to the 'UN Common System of salaries, allowances and other conditions of service' managed by the International Civil Service Commission (ICSC). ${ }^{7}$

In fact, the relationship agreements concluded by the IBRD, IDA and IFC with the UN do not provide for the application of common personnel standards, nor do they oblige the WB Organizations to be part of the UN Common System.

For instance, pursuant to para 1 of Art X of the UN-IBRD Relationship agreement,

The UN and the Bank will consult from time to time concerning personnel and other administrative matters of mutual interest, with a view to securing as much uniformity in these matters as they shall find practicable and to assuring the most efficient use of the services and facilities of the two organizations [emphasis added].

The relationship agreements concluded between the UN and the majority of the other specialised agencies contain instead a provision on personnel arrangements with a view to develop common personnel standards and avoid serious discrepancies in terms and conditions of employment. $^{8}$

\footnotetext{
${ }^{4}$ See UN Economic and Social Council, Resolution 13 (III) 'Co-ordination Committee', 21 September 1946 (document E/231). On 21 September 1946, at the request of ECOSOC, the Secretary General established the Administrative Committee on Coordination as a standing committee to supervise the implementation of the relationship agreements between the UN and the then existing three specialised agencies. In 2001 the Administrative Committee on Coordination was renamed UN System Chief Executives Board for Coordination (CEB).

${ }^{5}$ The UNSMS was officially established by UN General Assembly resolution 59/276 of 23 December 2004, to unify all security mechanisms in place to protect civilians and military staff members within the UN System. Security policies of the UNSMS are initiated, developed and reviewed by the Inter-Agency Security Management Network (IASMN), a specialised network of the HLCM. The HLCM either directly decides on the recommendations made by the IASMN or recommends their endorsement and implementation to the CEB. Mandatory security policies are collected in the UNSMS 2017. On the UNSMS see also Chap. 5, Sect. 5.3.4 (Annalisa Creta).

${ }^{6}$ The legal basis for the IBRD's participation in CEB and HLCM activities is Art X, para 2 of the UN-IBRD Relationship Agreement.

${ }^{7}$ The ICSC is an independent expert body established in 1987 by the UN General Assembly to regulate and coordinate the conditions of service of staff for the UN common system. See ICSC 2013 as well as ICSC 2017. ${ }^{8}$ For instance, Art XII.1 of the Agreement between the UN and UNESCO reads: 'The United Nations and the United Nations Educational, Scientific and Cultural Organization recognise that the eventual development of
} 
The purpose of this Chapter is to describe the WB Group's autonomous framework for employment relations with a view to assess how Duty of Care obligations owed to personnel performing official tasks, or on assignment, outside the Washington DC headquarters are implemented.

\subsection{Legal sources}

\subsubsection{Internal sources}

To determine the scope of the WB Group's Duty of Care, it is necessary to analyse the set of rules applicable to the conduct of staff members and their employment relationship with the Organization. ${ }^{9}$

As affirmed by the World Bank Administrative Tribunal (WBAT) in its first decision, the respective rights and duties of the WB Group and its staff are to be found in the 'internal law' of the Organization. ${ }^{10}$

This internal legal framework includes the Articles of Agreement of the different Organizations, the By-Laws, manuals, circulars, notes and statements issued by the management of the Bank. ${ }^{11}$ Further elements of the World Bank's staff legal relationship may be found in the 'Personnel Manual, the Field Office Manual, various administrative circulars and in certain notes and statements of the management'. ${ }^{12}$

It has to be underlined, though, that the Tribunal also maintained that 'Not all the provisions of these manuals, notes, statements are included in the conditions of employment. Some of them have the character of simple statements of current policy or lay down certain practical or purely procedural methods of operation. It is, therefore, necessary to decide in each case whether the provision

\footnotetext{
a single unified international civil service is desirable from the standpoint of effective administrative coordination, and with this end in view agree to develop common personnel standards, methods and arrangements designed to avoid serious discrepancies in terms and conditions of employment, to avoid competition in recruitment of personnel, and to facilitate interchange of personnel in order to obtain the maximum benefit from their services'.

${ }^{9}$ On the law of the international civil service, see Jenks 1962; Balladore Pallieri 1969; Amerasinghe 1994; Villalpando 2016a.

${ }^{10}$ WBAT, de Merode et al. v. the World Bank, 5 June 1981, Decision No. 1, para 36 (see Annex YZ, Case 44).

${ }^{11}$ WBAT, de Merode, para 18. See also Shihata 2000, $\mathrm{p} 709$. The legal basis for the adoption of these internal rules is to be found in Art V, Section 5, let. (b) of the IBRD Articles of Agreement, according to which 'The President shall be chief of the operating staff of the Bank and shall conduct, under the direction of the Executive Directors, the ordinary business of the Bank. Subject to the general control of the Executive Directors, he shall be responsible for the organisation, appointment and dismissal of the officers and staff'.

${ }^{12}$ WBAT, de Merode, para 22.
} 
constitutes one of the conditions of employment'. ${ }^{13}$ This distinction was subsequently applied by the WBAT in several judgments.

After the establishment of the WBAT, the adoption of a new, more comprehensive and detailed employment framework became necessary. In 1983 the Executive Directors of the IBRD and IDA adopted the Principles of Staff Employment which embody 'the general conditions and terms of employment with the Organisation' and set forth 'the broad policies in accordance with which the President shall organise and manage the staff of the World Bank [IBRD and IDA] and the IFC'. ${ }^{14}$

The 1983 Principles, however, were far from being exhaustive and needed to be supplemented by more detailed rules. In fact, according to Principle 1, 'The President [...] shall develop, provide, and maintain such programmes and Staff Rules consistent with these Principles, as he considers necessary to the efficient conduct of the Organisations' business'.

Nowadays, the most important internal legal source regulating the status of international civil servants within the WB Group is the 'Staff Manual', made up of over 50 Staff Rules. Based on the 1983 Principles, Staff Rules establish the basic rights and obligations of the Bank and its staff. They cover various aspects of the employment relationship, ranging from personnel management and organization, recruitment, appointment, probation, compensation, reassignment, termination and retirement, to health insurance schemes, tax allowances, misconduct and conflict resolution.

Staff Rules are accompanied by the WB Code of Conduct, ${ }^{15}$ which provides general guidance and complements rules and policies of the WB Group. When there is a discrepancy between the Staff Rules and the Code of Conduct, the Staff Rules prevail.

Furthermore, Administrative Manual Statements (AMSs) - which contain policies, procedures and standards concerning the WB Group's management and administration ${ }^{16}-$ and WB Group Procedures - which define the Organization's decision-making processes and approval mechanisms ${ }^{17}$ - might become relevant for employment relations when they define the procedures to be followed in certain circumstances (as in the case of the WB Group Procedure on official travel).

Over time, the evolving practice of the Organization made this body of law increase considerably, with employment rules constantly amended to adapt to new needs and challenges.

\subsubsection{External sources}

\footnotetext{
${ }^{13}$ WBAT, de Merode, para 22.

${ }^{14}$ Preamble to the 1983 Principles.

${ }^{15}$ World Bank 2009.

${ }^{16}$ See Leroy 2011, p 57.

17 The WB Group's Operational Policies and Procedures are collected in the so-called Operational Manual. They should be consistent with the Articles of Agreement.
} 
In addition to the internal rules and regulations of the Organization, the WBAT has relied on external sources such as the 'general principles of law'18 and 'solutions worked out in sufficiently comparable conditions by other administrative tribunals, particularly those of the UN family'. ${ }^{19}$

Among the general principles of law, the WBAT acknowledged the principles of nondiscrimination ${ }^{20}$ and non-retroactivity, ${ }^{21}$ the duty to protect staff against sexual harassment, ${ }^{22}$ as well as 'pacta sunt servanda, good faith, due process, estoppel (including protection of legitimate expectations), and unjust enrichment'. ${ }^{23}$

For international rights and duties stemming from the WB's international legal personality, while the UNDT acknowledged that 'international administrative tribunals may rely on, among other sources, general principles of law - including international human rights law, international administrative law and labour law - which may be derived from, inter alia, international treaties and international case law', ${ }^{24}$ no such explicit understanding can be found in WBAT case law.

The only reference to the need to protect fundamental human rights is found in Sharpston, ${ }^{25}$ where the applicant referred to the International Covenant on Civil and Political Rights, the European Convention on Human Rights and the American Convention on Human Rights. The Tribunal, however, limited itself to acknowledging that the right to be protected from inhuman or degrading treatment is 'entirely uncontroversial', but declared the application otherwise inadmissible.

This notwithstanding, it can be maintained that all International Organizations, as subjects of international law, are bound by customary international law rules. In fact, as already affirmed in 1980 by the ICJ in its Advisory Opinion concerning the Interpretation of the Agreement of $25^{\text {th }}$ March 1951 between the WHO and Egypt, 'International organisations are subjects of international law and, as such, are bound by any obligations incumbent upon them under general rules of international law' ${ }^{26}$

\footnotetext{
${ }^{18}$ WBAT, de Merode, para 25.

${ }^{19}$ WBAT, de Merode, para 28. See also Seatzu 2015; Hansen 2012a; Hansen 2012b; Hansen 2007.

${ }^{20}$ WBAT, Mendaro v. IBRD, 4 September 1985, Decision No. 26, para 20 (see Annex YZ, Case 45). The applicant claimed the non-observance of the conditions of her employment because of alleged discrimination on the basis of sex and sexual harassment, imputable to the respondent. It is worth noting that the Tribunal decided that the application was inadmissible because some of the events leading to the complaints had occurred before the establishment of the WB Tribunal and for those arising afterwards, the plaintiff's application was not filed in time. See also US Court of Appeals of the District of Columbia Circuit, Mendaro v. World Bank, 27 September 1983, 717 F.2d 610, where the Court affirmed the IBRD's immunity from suits in employment disputes.

${ }^{21}$ WBAT, de Merode, paras 34 and 47.

${ }^{22}$ Harassment, sexual harassment, discriminatory practices, retaliation (including for alleged whistleblowing) and abuse of authority amount to staff misconduct under Staff Rule 3.00 and constitute grounds for disciplinary action. The Office of Ethics and Business Conduct is competent to review these misconduct allegations.

${ }^{23}$ WBAT, C.L. v. IBRD, 26 September 2014, Decision No. 499, para 73.

${ }^{24}$ UNDT, Obdeijn v. UN Secretary-General, 10 February 2011, Judgment No. UNDT/2011/032, paras 30-31.

${ }^{25}$ WBAT, Sharpston v. IBRD, 23 July 2001, Decision No. 251, para 56 (see Annex YZ, Case 46).

${ }^{26}$ ICJ, Interpretation of the Agreement of 25 March 1951 between the WHO and Egypt, Advisory Opinion, 20 December 1980, para 90. See also Seyersted 1967, p 427; Herz 2010, p 146.
} 
Due to the generalised reluctance of international financial institutions to acknowledge their human rights obligations, the way these are complied with in staff relations is surrounded by uncertainty, especially when the standards are not clearly 'restated' in the Organization's internal rules.

\subsection{Scope of application}

\subsubsection{Ratione loci}

Rules and regulations may apply differently to staff members based at headquarters, assigned to country offices or travelling.

For instance, Administrative Manual Statement (AMS) 6.40 'Global Security' concerns security measures adopted to protect staff, facilities, possessions and programmes 'overseas' and therefore it does not cover the Washington DC headquarters.

\subsubsection{Ratione personae}

The 1983 Principles apply to all staff members, who are any person appointed by the President to perform services for the WB Group, 'except that, considering the particular characteristics of their appointments, the President may vary the application of the Principles to persons on Part Time, Temporary, Trainee, Consultant or Executive Director's Assistant appointments, or to any new types of appointment that may be established'.

The employment status reflects the type of contract signed by a staff member. To date, all appointment types including but not limited to Short Term Consultant (STC), Short Term Temporary (STT), Extended Term Consultant (ETC), Extended Term Temporary (ETT), Junior Professional Associate (JPA), Regular, Local Staff Regular, ${ }^{27}$ Open-Ended, Term, Executive Director Assistant and Special Assignments are subject to Staff Rules and applicable WB Group policies. ${ }^{28}$

Usually, the letter of appointment of a staff member - even of a short-term consultant explicitly states that the appointment 'is subject to the Staff Rules currently in effect and as they may be amended from time to time' ${ }^{29}$

\footnotetext{
${ }^{27}$ Local Staff Regular is a full-time appointment of indefinite duration, made before July 1998, of a person recruited to serve at a WBG country office.

${ }^{28}$ In 2016, Staff Rule 4.01 was amended to reorganize and redefine the types of appointment of staff. Short and extended term consultants are included among the staff members of the WB Group.

${ }^{29}$ Source: samples of appointment letters (for Short Term and Extended Term Consultant positions) on file with Author.
} 
Positions in country offices, irrespective of level, are subject to local recruitment. This ensures depth of country knowledge and is considered a critical complement to international recruitment.

Benefits and pay applicable to locally recruited staff may vary according to the type of their appointments (Short Term Appointment, Temporary Appointment, Local Staff Regular Appointment and staff on Localisation Plus). ${ }^{30}$

Country office appointed staff members are eligible to receive hazard and fragility pay if they hold a Term, Local Staff Regular or an Open-Ended Appointment and if they are assigned to work indefinitely in a country classified as 'Fragile and Conflict Affected Situation (FCS)' or a 'Hazardous FCS location'. 31

FCS locations include countries or territories with a low harmonized CPIA country rating, ${ }^{32}$ and/or the presence of a UN and/or regional (for example EU, NATO, AU) peace-keeping or political/peace-building mission during the last three years. ${ }^{33}$

Hazardous FCS locations refers to duty stations designated by the UN as eligible for 'Danger Pay'.

\subsection{Content of the WB Group's Duty of Care obligations}

Neither the Articles of Agreement nor the Staff Manual contains a comprehensive definition of the Duty of Care, but various policies and directives cover the wide spectrum of the duties arising from it.

The 1983 Principles of Staff Employment identify the general obligations of the IBRD, IDA and IFC in their relations with staff members: the duty to act with fairness and impartiality, the duty to follow due process, the duty of non-discrimination and the duty to 'respect the essential rights of staff members that have been and may be identified by the WB Administrative Tribunal'. ${ }^{4}$

In particular, the WB Group's Organizations - and every personnel member according to their employment contract - have a duty to 'make all reasonable efforts to ensure appropriate protection

\footnotetext{
${ }^{30}$ In general, internationally recruited staff working in country offices are paid in US Dollars, while locally recruited staff are paid in local currency (with some exceptions). See Das et al. 2017, 10.

${ }^{31}$ See Staff Rule 6.28 "Hazard and Fragility Pay", issued in October 2017, which outlines the non-pensionable compensation premium provided by the WB Group to extend reasonable assistance to eligible staff members indefinitely based in a country office designated as a Fragile and Conflict Affected Situation (FCS). For the purpose of Staff Rule 6.28 hazardous FCS locations are those duty stations designated by the UN eligible for danger pay. See also Chap. 5, Sect. 5.4.1(d).

32 The Country Policy and Institutional Assessment - CPIA rating measures countries against a set of criteria related to economic management, structural policies, policies for social inclusion and equity, as well as public sector management and institutions.

${ }^{33}$ See http://www.worldbank.org/en/topic/fragilityconflictviolence/brief/harmonized-list-of-fragile-situations

${ }^{34}$ Principle 2.1.
} 
and safety for staff members in the performance of their duties' and to 'take such measures as may be necessary to protect the international character of the staff in discharging their duties' ${ }^{35}$

All WB Group offices are therefore responsible for taking operational and physical security measures to protect staff, facilities, and programmes. Likewise, individuals have a personal obligation to be conscientious and to reduce risks. ${ }^{36}$

Other rules relevant for the implementation of the Duty of Care are set forth in the Staff Manual, AMSs and other directives and procedures.

For overseas assignments, AMS 6.40 'Global Security' establishes a clear division of responsibility among the WB Group's Country Office Manager, the UN, and the host country for the implementation of security actions and programmes.

Looking at the specific obligations incumbent on the WB Group identified in the introductory Chapter of the book, the following can be found.

\subsubsection{Non-discrimination}

Non-discrimination is one of the key tenets of international civil service law. It is enshrined in the 1983 Principles of Staff Employment: the Organizations 'shall not differentiate in an unjustifiable manner between individuals or groups within the staff and shall encourage diversity in staffing consistent with the nature and objectives of the Organisations' ${ }^{37}$

In its first case the WBAT acknowledged non-discrimination as one of the general principles of law included in the conditions of employment. ${ }^{38}$ It encompasses gender, racial/ethnic and age discrimination.

\subsubsection{Health and safety of personnel}

As recognised by the WBAT in EI v. IBRD, ${ }^{39}$ the Organizations of the WB Group have a duty to provide a safe and healthy work environment to their staff. This is consistent with Principle 2.1, let.

\footnotetext{
${ }_{36}^{35}$ Principle 2.1(b) and (f).

${ }^{36}$ Principle 3.

${ }^{37}$ Principles 2.1 and 9.1 .

${ }^{38}$ WBAT, de Merode, para 34.

${ }^{39}$ WBAT, E.I. v. IBRD, 25 October 2017, Decision No. 569, para 90. In this case the Tribunal found that the IBRD's Duty of Care includes the remediation of environmental hazards that may adversely affect the health of a staff member in the workplace and the subsequent proactive monitoring of the situation. Even the temporary reassignment of the staff member to a different location (while keeping almost the same duties and responsibilities) was deemed to satisfy the Bank's Duty of Care towards the applicant (para 103). Finally, the Tribunal found that requiring the applicant to undergo an independent medical evaluation prior to allowing her return to the original workplace amounts to a proper discharge of the Bank's Duty of Care (para 119).
} 
(b) which provides that 'The organisations shall make all reasonable efforts to ensure appropriate protection and safety for staff members in the performance of their duties.'

Moreover, Principle 6, Section 6.2, let. (d) establishes that the Organizations have a duty to 'establish and maintain programmes to promote the health and wellbeing of staff members and to provide financial protection and assistance for staff members and their families, including but not limited to annual, maternity and sick leave, coverage for medical and hospitalization expenses, accidents and loss of life'.

Accordingly, Staff Rule 6.07 'Health Program and Services' sets forth provisions on healthrelated matters. ${ }^{40}$ This rule applies to staff members assigned at headquarters and country offices of the IBRD, IDA, IFC, ICSID and MIGA. The purpose of the policy is to ensure a safe work environment and to protect the health of staff and of their immediate families. It includes provisions on inoculations and medications to staff when they engage in operational travel or when they relocate due to change of duty station, protocols on medical clearance for staff travelling to a country dealing with a public health emergency, as well as on medical evacuation and other general health and safety standards in the workplace.

In particular, Staff Rule 6.07 establishes that, to ensure adequate medical treatment in the event of acute illness or injury when appropriate treatment is not available locally, the WB Group evacuates staff and their dependents to the closest location where appropriate medical treatment can be provided. Persons who may be evacuated includes staff members (as defined above in par. 12.3.1) and their immediate families in duty stations outside the US, Australia, New Zealand, Japan and Western Europe as well as staff members and their spouse/domestic partner who are on operational travel outside the US. ${ }^{41}$

When a public health emergency is declared by the World Health Organisation (WHO), the Centres for Disease Control and Prevention (CDC) or the European Centre for Disease Prevention and Control (ECDC), with travel restrictions issued, a pre-departure briefing and post-travel monitoring 'may also be required' once the traveller has been medically cleared (para 3.05). These procedures are therefore left to the discretion of the Organization.

AMS 3.00 'Operational Travel' may apply, but the document is not disclosed other than to staff members.

\subsubsection{Information on potential dangers and adequate training}

\footnotetext{
${ }^{40}$ See also Principle 6.2(d).

${ }^{41}$ See also, infra, paragraph 12.4 .4 on the duty to evacuate internationally and locally recruited staff according to AMS 6.40 'Global Security'.
} 
An important aspect of the Duty of Care is the duty to adequately inform and prepare staff in the predeployment phase, to ensure their full awareness of the challenges to be faced. This is especially true for staff members that are to be dispatched in risk areas and in fragile and conflict affected countries.

While the Administrative Manual does not explicitly refer to the duty to inform staff on potential threats and dangers, according to AMS 6.40 on 'Global Security' (on which see also infra), Country Office Managers are responsible for familiarising resident and mission staff with the local security situation, security procedures and communications.

Furthermore, in country offices, Security Focal Points (SFPs) assist staff, dependents and benefit travellers by managing their safety and security on the ground and by providing security information and advice as well as training (for instance, on how to properly use alarm systems and on emergency communications and evacuations procedures). SFPs are staff members who, in addition to their regular duties, have volunteered for (or been appointed to) the position without having a professional security background. Therefore, in 2017, to ensure a more secure and safe environment for WB Group personnel, the Corporate Security Division of the General Services Department (GSDCS) decided to offer SFPs an e-learning training and certification programme.

Moreover, as far as adequate training is concerned, the WB Group Procedure on 'Official Travel' provides for a mandatory security responsiveness e-learning course for all staff members prior to official travel, in the absence of which trip requests cannot be approved.

In the end, it is worth highlighting that the duty to provide adequate information also concerns gender-based security threats which may result from a number of factors, including gender, gender identity, or sexual orientation. Acknowledging these security concerns, in 2016 the UNSMS promulgated a new policy according to which staff members should be duly informed on genderbased security risks. To date, however, it is not possible to establish whether the WB Group has implemented this policy or to what extent. ${ }^{42}$

According to the LGBTI staff group 'UN Globe', in order to enable an informed decision as to whether or not to accept an assignment to a particular duty station, complete information on the following circumstances should be disclosed: possibility to obtain residence visas or employment permits for legal same-sex partners of staff in the country of destination; high-levels of recorded incidents of homophobia or transphobia; as well as access to medical care also in the case of STD medical conditions (like HIV/AIDS). ${ }^{43}$

At the time of writing, the GSDCS of the WB Group is updating its policy on 'Non-Family Duty Station Designations' and might decide to take into account the concerns mentioned above.

\footnotetext{
${ }^{42}$ See UNSMS Security Policy Manual, Chapter IV Security Management, Section M ‘Gender Considerations in Security Management', 2016.

${ }^{43}$ UN Globe 2015.
} 


\subsubsection{Specific challenges and threats}

Due to challenges and threats posed by worldwide increasing political and criminal violence, the AMS 6.40 on 'Global Security' addresses the WB Group's responsibility 'to protect its staff, facilities, and programmes overseas, and the mechanisms whereby that is accomplished', setting out guiding principles, decision-making procedures and the responsibilities of key stakeholders.

The AMS 6.40 is an excellent and accurately drafted policy which applies to staff members of the WB Group and eligible dependents as well as to consultants hired under direct contract, that is, having staff appointments with the Group, but not to employees of companies contracted by the WB Group through corporate procurement even if deployed to work in dangerous environments. No distinction is made between protection provided to staff recruited internationally or locally, except as regards to evacuation and residential security guards. As for evacuations, internationally recruited staff are evacuated from the country, whereas locally recruited staff (be they foreigners or nationals of the host State) are relocated within the country if this is feasible. ${ }^{44}$

A clear division of responsibility for the implementation of security actions and programmes is set forth and different roles are attributed to the host country, the United Nations, and the WB Group's Country Office Manager. At the same time, individuals are required to take personal security measures to reduce risk against them, their families and belongings. ${ }^{45}$

The host country is primarily responsible for the security of WB Group staff, their dependents and property. The WB Group, however, should put in place separate planning and emergency reaction mechanisms independent from the host government actions or its response capacity.

The UN is responsible for interagency arrangements for the protection of UN Organizations and specialised agencies, including the WB Group, against hazardous situations out of the host government control.

In countries where the WB Group maintains an office (either IBRD or IFC), the Country Office Manager remains responsible for the security and safety of WB Group's resident staff and

\footnotetext{
${ }^{44}$ This provision should be compared with the UNSMS Security Policy Manual, Chapter IV, Section D, para 13, according to which "locally-recruited personnel and/or their eligible family member may be evacuated from a duty station only in the most exceptional cases in which their security is endangered as a direct consequence of their employment by organizations of the United Nations common system" [emphasis added]. On the duty to provide functional protection on an equal basis to internationally and locally recruited personnel see Ruzié 1999, p 435.

${ }^{45}$ AMS 6.40 'Global Security', para 1. According to the UNSMS Security Policy Manual 'Personnel employed by the organizations of the UN System are accountable to their respective organizations. All such personnel, regardless of their rank or level, have the responsibility to abide by security policies, guidelines, directives, plans and procedures of the UNSMS and its organizations' (UNSMS, Security Policy Manual, Chapter II, Section B, para 28).
} 
visitors, as well as travelling staff. In locations where neither the WB nor IFC have an office, the local UN office undertakes responsibility for security matters.

Country Office Managers ensure that the security and crisis management programmes are correctly implemented, monitor local security conditions, report significant developments and incidents, and brief resident and mission staff on the local security situation and relevant procedures. They are responsible for the safety of staff and consultants while they are at their residences, at hotels, or in their vehicles either on duty or non-duty travel.

The Country Office Manager is assisted by Security Champions who serve as SFPs, providing assistance to staff, dependents and benefit travellers.

Preventive and crisis management procedures should be put in place for various incidents, including but not limited to: bomb threats and bombings, social unrest, civil war, insurrection or coup d'Etat, fire, kidnapping or hostage taking, medical emergencies, multiple cases of injury or death, natural disasters, terrorist threats or attacks and major public transport accidents. ${ }^{46}$

The AMS 6.40 also establishes security guidelines for medical emergencies and evacuations which apply in combination with Staff Rule 6.07 (see supra).

Notably, in 2017 the GSDCS developed a roadmap for the development of a new WB Group Global Security Management Strategy, building upon the AMS 6.40. ${ }^{47}$ The new Global Security Management Strategy is going to comprise: a new Framework of Accountability for the Bank Group Security Management System; an updated Security Risk Management framework; new or updated policies and procedures on 'Country Evacuation and Relocation', 'Travel/Road Safety', 'Operating Status', 'Non-Family Duty Station Designations'; as well as a newly developed Critical Incident Review Process in the event of death or serious injury of a WB Group employee. ${ }^{48}$

\subsubsection{Effective medical services after an incident has occurred}

The WB Group's duty to provide staff members with effective medical services to fully recover from any physical injury or mental health condition came under scrutiny for the first time when the WBAT was called to adjudicate the Lansky case. ${ }^{49}$

\footnotetext{
${ }^{46}$ See also AMS 6.30C, Incident Categories; the WB Group (1999) Crisis Management Manual and the WB Group (2001) Crisis Action Plan Template.

${ }^{47}$ The AMS 6.40 dates back to 2007.

${ }^{48}$ See WB Group Internal Audit (2017) Special Review of the Formulation of the New WBG Global Security Management Strategy, WBG FY17-07.

${ }^{49}$ WBAT, Tamara Lansky (No. 1 and No. 2) v. IFC and IBRD, 9 December 2009, Decision No. 425 and WBAT, Tamara Lansky (No. 3) v. IFC and IBRD, 29 October 2010, Decision No. 442 (see Annex YZ, Case 47).
} 
At the end of 2005, Tamara Lansky, an IFC Senior Investment Officer, left her hotel in Kinshasa (Democratic Republic of Congo (DRC)) on a pickup truck with a driver heading towards the airport. They did not know that the road they were travelling on was under the control of paramilitary forces opposed to the government and, apparently, they did not know either that a heightened security level had been recently declared. Ms. Lansky's car was stopped and surrounded by men trying to open the vehicle doors, while the occupants of another car were forced out and assaulted before them. Ms. Lansky managed to escape and reached the airport without physical injuries. Back in the US, however, she was diagnosed with severe Post Traumatic Stress Disorder (PTSD) and was subsequently granted long term disability. ${ }^{50}$

In 2009, upon termination of her employment, the applicant and the WB entered a Memorandum of Understanding (MoU), whereby Ms. Lansky agreed to settle and release any and all claims or causes of action alleging negligence or breach of contract arising from the security incident in the DRC. ${ }^{51}$

Because of the MoU, the Lansky case could not concern the WB Group's poor implementation of safety and security standards in a high-risk environment such as the fragile and conflict affected DRC. Instead, the claim focused on the entire process of administration of the Workers' Compensation and Disability Programmes. ${ }^{52}$

Ms. Lansky maintained that she had to deal with new retroactive reimbursement policies and procedures, with claim adjustors continuously changing, delays, requests for additional information and negligence (she was referred to a medical practitioner without experience in PTSD). As admitted by the WBAT, this 'would commonly result in arbitrariness, and denial of due process on the part of the administrator'. 53

The Tribunal noted that Principle 2.1 applied: 'The Organizations shall at all times act with fairness and impartiality and shall follow a proper process in their relations with staff members'. However, the Tribunal also considered that the applicant had waived her right to file claims arising from the alleged failure of the Bank to comply with said standards. ${ }^{54}$ This notwithstanding, in the light of the exceptional circumstances of the case and in a rather unorthodox way, the WBAT recommended the WB to develop - in cooperation with the Staff Association - appropriate

\footnotetext{
${ }^{50}$ WBAT, Lansky (No. 1 and No. 2), paras 5-19.

${ }^{51}$ WBAT, Lansky (No. 1 and No. 2), para 15.

${ }^{52}$ WBAT, Lansky (No. 1 and No. 2), para 36. The administration of the programme was (and it is) outsourced to a third-party administrator contracted by the WB Group which in turn contracted out some of its responsibilities to a subcontractor.

${ }^{53}$ WBAT, Lansky (No. 1 and No. 2), para 45.

${ }^{54}$ See WBAT, Lansky (No. 1 and No. 2), para 52.
} 
procedures to process payment or reimbursement claims under the Workers' Compensation and Disability Programmes, although without specifying what Duty of Care standards had to be met.

Eventually, Staff Rule 6.11 'Workers' Compensation Program' on compensation and benefits in the event of service-incurred illness, injury or death and Staff Rule 6.22 'Disability Insurance Program' were revised taking into account the WBAT's recommendations. This outcome can be considered illustrative of the learning culture of the WB Group.

Lastly, it is worth noting that Ms. Lansky was not covered by the Malicious Acts Insurance Policy (MAIP) which, since 1990, is typically offered by the Organizations of the UN Common System to their internationally and locally recruited staff members, consultants as well as official visitors while travelling or on mission. ${ }^{55}$

The MAIP is particularly important for the discharge of Duty of Care obligations as it covers accidents resulting in death or disability (including PTSD) caused by war, invasion, hostilities, acts of foreign enemies, civil war, revolution, rebellion, insurrection, military or usurped power, riots or civil commotion, sabotage, explosion of war weapons and terrorist activities.

Initially the MAIP was applied by the UN only in designated duty stations classified as dangerous, but nowadays the policy applies worldwide. Coverage for death or disability under the MAIP is in addition to compensation that may be awarded in the event of death, injury or illness of a staff member while on official duty (which is payable under Appendix D to the UN Staff Rules or comparable compensation schemes). Moreover, the MAIP has a broader coverage as it applies to all international and locally recruited staff and consultants. The policy is without cost to insured individuals and the Organization bears the full premium.

Strict adherence to security measures by insured individuals is imperative as failure to do so could result not only in tragic incidents, but also in denial of related insurance claims.

To date, the WB Group does not maintain a MAIP. However, under its staff benefits programme, it provides life insurance, accidental death and dismemberment, survivorship and workers compensation benefits. These are provided on a 24 hour/7 day basis as a staff benefit, or a 'while on official duty' benefit. ${ }^{56}$ Certain benefits, though, are provided under commercial insurance policies which have open market based conditions and exclude, for example, coverage for war. Staff

\footnotetext{
${ }^{55}$ In the area of insurance, a stock-taking exercise carried out by CEB in 2010-2012 identified broad differences of coverage and compensation between international staff, local staff and non-staff personnel. See HLCM, 'Comprehensive Mapping of Benefits, Entitlements, Insurance Related to Service Incurred Injury, Illness, Death and Disability in the UN System', CEB/2010/HLCM/21/Add. 1, 17 September 2010 as well as the undisclosed document $\mathrm{CEB} / 2012 / \mathrm{HLCM} / 17$ the content of which is summarised in CEB, 'Conclusions of the $24^{\text {th }}$ Session of the High-Level Committee on Management', CEB/2012/5, 22 October 2012, paras 28-48.

${ }^{56}$ Flex or temporary staff members may receive lower (institution paid) benefits than regular staff as reflected in their different compensation or remuneration arrangements.
} 
members of the WB are therefore generally covered only in conflict situations which are less extreme than those faced by UN personnel. Because of the increasing involvement of the WB Group's Organizations in fragile and conflict affected countries, however, the insurance policy of the WB Group may need to be updated soon.

\subsubsection{Exercise of functional protection}

The WB has the right to provide functional protection to its agents to ensure the efficient and independent performance of their duties. The exercise of functional protection should be considered an implied power necessary for the fulfilment of the Organization's mandate, flowing from its international legal personality. The protection, therefore, extends only to activities carried out in the agent's official capacity, whereas private acts are not covered.

The existence of a duty to exercise functional protection for the denial of a visa by the State of the seat was discussed in the Alrayes case. ${ }^{57}$ The US G4 visa of Mr. Alrayes, a Saudi Arabian national who worked as IFC Senior Officer on a Term contract, was cancelled for alleged terrorist activities while he was on a routine mission to the Gulf States. It took more than 4 years for Mr. Alrayes to obtain a visitor's visa for the US after being interviewed twice by the FBI. During all this time, he was forced to live abroad, away from his family and children, in the uncertainty of when he would be eventually cleared of accusations and experiencing financial difficulties. ${ }^{58}$ The IFC provided assistance, also offering Mr. Alrayes new terms of appointment, but refused to take legal action against the US, resorting only to diplomatic channels.

Upon his return to the US, Mr. Alrayes filed an application against the IFC before the WBAT, contending that the IFC had 'failed in its duty of care'.${ }^{59}$ He challenged a number of IFC decisions, including his placement on a Short-Term Assignment and the termination of his employment under a Memorandum of Understanding, and asked for the reimbursement of the legal and travel costs he had incurred as well as for separation payments.

The WBAT dismissed the majority of his claims, only awarding the applicant a small compensation. The claim concerning the IFC's decision not to seek a mandamus writ was ruled inadmissible for lack of exhaustion of internal remedies.

\footnotetext{
${ }^{57}$ WBAT, Alrayes v. IFC, 13 November 2015, Decisions No. 520 (Preliminary Objection) and WBAT, Alrayes v. IFC, 8 April 2016, Decisions No. 529 (Merits) (see Annex YZ, Case 43).

${ }^{58}$ On these grounds, the WBAT recognised the existence of exceptional circumstance to excuse Mr. Alrayes's delays in filing his claims (WBAT, Alrayes (Preliminary Objection), para 104). At the same time, however, the WBAT affirmed that Mr. Alrayes should have filed his claims at least within 120 days of his return to the US. Only some of the applicant's claims were therefore deemed admissible.

${ }^{59}$ WBAT, Alrayes (Merits), para 41.
} 
It should be underlined, though, that in a similar situation the UN Dispute Tribunal reached a different conclusion. The Hassouna case ${ }^{60}$ concerned a UN staff member placed on persona non grata (PNG) status by the government of Sudan. The UNDT recognised that the Secretary General is entitled to request the host country information on the reasons leading to the PNG decision to determine whether or not the staff member was acting in his/her official capacity. The Tribunal also affirmed that 'in the case the host country is not forthcoming with information as to the basis for his/her expulsion or the reasons, if any, do not justify a PNG decision, [...] a change in the terms and conditions of the staff member's contract or non-renewal is not an option open to the SecretaryGeneral. ${ }^{61}$ In fact, under such circumstances, 'it is the duty of the Organization to take steps to alleviate the predicament in which the staff member finds himself/herself following his/her expulsion from the host country.' 62

Despite the fact that the Hassouna case concerned a host State while the Alrayes case concerned the State of the seat, we can contend that the IFC erred, first, in placing Mr. Alrayes on a short-term assignment and, then, in terminating his employment contract.

\subsection{Administrative procedures}

According to Principle 9.1, staff members have the right to fair treatment in matters concerning their employment and, when disputes arise, they have a right to file their case.

To this end, different mechanisms have been established over time. The WB conflict resolution system offers, in fact, a wide range of services to assist staff in the resolution of disputes. Mediation services are offered to facilitate communication among staff members and assist in reaching mutually acceptable solutions to workplace related conflict. ${ }^{63}$

The Ombudsman office has a broad mandate to act as an impartial source of assistance for the informal resolution of staff-related issues. ${ }^{64}$ The Respectful Workplace Advisors (RWAs) are coordinated by the Ombuds Services Office. They are a network of volunteer peers who serve as an informal and confidential source of assistance to staff facing challenging workplace problems.

\footnotetext{
${ }^{60}$ UNDT, Hassouna v. Secretary General of the United Nations, 10 July 2014, Judgement No. UNDT/2014/094 (see Annex YZ, Case 40).

${ }^{61}$ UNDT, Hassouna, para 51.

${ }^{62}$ Ibid.

${ }^{63}$ See Staff Rule 9.01.

${ }^{64}$ See Staff Rule 9.02.
} 
The Peer Review Services facilitate the resolution of employment-related issues through a confidential process conducted before an impartial panel of peers (that is, volunteer staff members both at managerial and non-managerial level). ${ }^{65}$

The WBAT was set up in 1980, ${ }^{66}$ its Statute last being amended in 2009. The explanatory report of the IBRD President on the establishment of the WBAT referred to a principle accepted in many national legal systems and reaffirmed in the Universal Declaration of Human Rights which requires that, when administrative power is exercised and in the event of a dispute, a machinery should be available to accord a fair hearing and due process to the aggrieved party. ${ }^{67}$

The Convention on Privileges and Immunities of Specialized Agencies also requires International Organisations to 'make provision for appropriate modes of settlement of [...] disputes arising out of contracts or other disputes of private character to which the specialized agency is a party'. 68

The WBAT is called to decide on applications submitted by staff members of the IBRD, IDA and IFC alleging 'non-observance of their contracts of employment or terms of appointment', ${ }^{69}$ therefore including the 1983 Principles and all the applicable Staff Rules of the Organizations. ${ }^{70}$

It is worth noting that the WBAT's jurisdiction covers staff members only. The expression 'staff member', as defined by Art II (3) of the WBAT Statute, refers to an individual currently or formerly employed by the IBRD, IDA or IFC, as well as to anyone filing a claim on behalf of an incapacitated or deceased staff member or claiming a pension payment.

The Staff Association has no standing to file an application with the Tribunal either as an institution or on behalf of staff members. However, it may file amicus curiae briefs under WBAT Rule $23(2) .{ }^{71}$

Non-staff personnel - a very broad category which comprises individual contractors, individuals under service contracts, interns, trainees, job applicants and volunteers - have no standing

\footnotetext{
${ }^{65}$ See Staff Rule 9.03.

${ }^{66}$ The Board of Governors acted on the basis of Art V, Section 2, let. (f) of the IBRD Articles, according to which: 'The Board of Governors, and the Executive Directors to the extent authorized, may adopt such rules and regulations as may be necessary or appropriate to conduct the business of the Bank'.

${ }^{67}$ Memorandum to the Executive Directors from the President of the World Bank, 14 January 1980, Doc. R808, IDA/R80-8 and IFC/R80-6, paras. 1-2. See Amerasinghe 2014, p 319.

${ }^{68}$ Art IX, Section 31 of the Convention on Privileges and Immunities of Specialised Agencies, adopted by the General Assembly of the United Nations on 21 November 1947, entered into force on 2 December 1948, UN Treaty Series vol. 33, p. 261. See Okeke, 2016.

${ }^{69}$ WBAT Statute Art II.

${ }^{70}$ In its first decision, the WBAT held that a right to file a petition with the Tribunal is 'an integral part of the relationship between the Bank and its staff members' (WBAT, de Merode, para 21).

${ }^{71}$ See WBAT, The World Bank Staff Association vs. IBRD, IDA, IFC, 27 October 1987, Decision No. 40, paras 78-89.
} 
to lodge a complaint before the WBAT ${ }^{72}$ Therefore, the question concerning the level of protection guaranteed to non-staff members remains unanswered. ${ }^{73}$

In a few cases, national courts and the European Court of Human Rights ruled that an International Organization may be denied immunity from jurisdiction when the applicants have no other reasonable alternative means to protect their fundamental rights. ${ }^{74}$

Indeed, it can be advocated that, if the internal justice system of the relevant Organization is manifestly lacking, and no alternative means to protect individual fundamental rights are offered, national courts may exercise their jurisdiction. ${ }^{75}$

Additionally, in order to apply to the WBAT, the applicant should have previously exhausted 'all other remedies available within the Bank Group', acting within the time limits set, save under exceptional circumstances. ${ }^{76}$

According to the WBAT case-law, exceptional circumstances are to be determined on a caseby-case basis taking into account the particular facts of each case. ${ }^{77}$

The exhaustion of internal remedies requirement has constantly been interpreted in the sense of referring to 'formal remedies' (which include recourse to the Peer Review Services ${ }^{78}$ and the

\footnotetext{
${ }^{72}$ As for the UN justice system, proposals were put forward to create simplified mechanisms of dispute settlement for these individuals (see A/65/373 paras 165-183).

${ }^{73}$ In 1999, the IMF Administrative Tribunal held that it did not have jurisdiction to hear the claim of a former contractual employee of the Fund since his letter of appointment clearly stated that he would not become a staff member (IMFAT, A. v. IMF, 12 August 1999, Judgment No. 1999-1, para 9 (see Annex YZ, Case 28)). Notably, the IMFAT also declared that 'Equitable or other consideration do not enable the Administrative Tribunal to extend its jurisdiction to claims falling outside the express language of Article II of its Statute' (para 100).

${ }^{74}$ ECtHR, Waite and Kennedy v. Germany, Decision of 18 February 1999, App. No. 26083/94, paras 63-68. More recently reference should be made to ECtHR, Klausecker v. Germany, Decision of 6 January 2015, App. No. 415/07, paras 67-76 where the claimant was a job applicant at the European Patent Office as well as to ECtHR, Perez v. Germany, Decision of 6 January 2015, App. No. 15521/08, paras 65-66 on the shortcomings of the UN internal justice system before the 2009 reform. See also: ICJ, Effects of Awards of Compensation Made by the United Nations Administrative Tribunal, Advisory Opinion, 13 July 1954, para 57.

${ }^{75}$ The Morgan case is illustrative. In 1990, Morgan, an employee of a temporary employment agency who worked for two and a half years in a secretarial position at the IBRD brought a suit against the Bank before US courts. He claimed that IBRD officials and security guards had forcibly detained him against his will, denied him access to an attorney, accused him of stealing money without presenting evidence and harassed him. He sought compensatory and punitive damages for intentional infliction of emotional distress, false imprisonment, libel and slander. The US District Court of the District of Columbia dismissed his action acknowledging the IBRD's immunity (US District Court of the District of Columbia, Morgan v. IBRD, 13 September 1990,752 F. Supp. 492). More recently, however, it has been argued that, given the absence of an alternative means of tort redress, the outcome of a similar dispute might be different and immunity eventually denied by national judges (Dominicé 2001). See also Hammerschlag 1992, p 279; Reinisch and Wurm 2010, p 114.

${ }^{76}$ Art II (2) WBAT Statute. See also Staff Rule 11.01 'Claims'.

${ }^{77}$ See, for instance, WBAT, Alrayes (Preliminary Objection), paras 99-111.

${ }^{78}$ See Staff Rule 9.03 Peer Review Services, para 7.02. As of July 2009, the Peer Review Services replaced the Appeals Committee.
} 
Pension Benefits Administration Committee), as opposed to 'informal remedies' (like the Ombudsman Services and Mediation, which are considered purely voluntary remedies).

Ultimately, compensation (in the amount that is reasonably necessary to compensate the applicant for the actual damage suffered) can only be awarded by the WBAT when the rescission of the contested decision or the performance of the obligation invoked would 'not be practicable or in the institution's interest'. ${ }^{79}$

WBAT judgments are final and without appeal.

\subsection{Conclusions and recommendations}

Recent developments within the UN System require careful consideration as they might impact on the WB Group's implementation of its Duty of Care obligations in the near future.

In 2014, the HLCM established the High-Level Working Group on the Duty of Care with the objective of identifying key Duty of Care concerns within the UN System.

The Working Group identified the main shortcomings of the UN System and four crosscutting issues related to the need to: a) design and implement a pre-deployment resilience briefing, mandatory for all staff assigned to high risk duty stations and their families; b) enhance communication tools to overcome the staff's lack of awareness and understanding of Duty of Care obligations; c) strengthen medical and psychological services also at a preventive level in order to allow personnel to take informed decisions on the risks they may face; d) review the significant difference in allowances, benefits and entitlements for internationally-recruited versus locallyrecruited staff, including danger pay. ${ }^{80}$

A number of detailed recommendations covering the different aspects of the Duty of Care (psycho-social aspects; health and medical aspects; safety and security issues; human resources and administration) during the pre-deployment, deployment and post-deployment phases were also put forward, together with a proposed checklist to guide managers in high-risk environments. ${ }^{81}$

\footnotetext{
${ }^{79}$ Art XII (2) WBAT Statute. On this point, Sheed 2012, p 233.

${ }^{80}$ See Final Report of the HLCM Working Group on 'Reconciling Duty of Care for UN personnel while operating in high-risk environments', CEB/2016/HLCM/11, 15 March 2016.

See also the eleven common principles adopted in 2014 by the CEB to guide the UN System in supporting the implementation of the 2030 Agenda for sustainable development. Among these, Common Principle n. 11, entitled 'Duty of Care', establishes that: 'The organizations of the UN System will preserve and foster the health and wellbeing as well as safety and security of their staff - while remaining committed to stay and respond to the ever-increasing demand for their services, despite the often deteriorating conditions in which those services are being delivered' (CEB 2016).

${ }^{81}$ See HLCM Committee on Management, Duty of Care Task Force - Interim Report, CEB/2017/HLCM/16, 14 September 2017.
} 
These recommendations are addressed to all the members of the UN System, including the Organizations of the WB Group. To date, however, the WB Group has failed to engage proactively in the activities of the Working Group on the Duty of Care. Hopefully, the positive momentum generated within the UN System will prompt the WB Group to further improve and consolidate its Duty of Care framework. 


\section{Reference list}

Akehurst M (1967) The Law Governing Employment in International Organizations. Cambridge University Press, Cambridge

Amerasinghe C (1987) Sources of International Administrative Law. In: Ziccardi P (ed), International Law at the Time of Its Codification - Essays in Honour of Roberto Ago. Giuffré, Milano, pp 67-95

Amerasinghe C (1994) The Law of the International Civil Service. Clarendon Press, Oxford

Amerasinghe C (2005) Principles of the Institutional Law of International Organisations. Cambridge University Press, Cambridge

Amerasinghe C (2010) Accountability of International Organisations for Violations of the Human Rights of Staff. In: Wouters $\mathrm{J}$ et al. (eds), Accountability for Human Rights Violations by International Organisations. Intersentia, Antwerp, pp 527-544

Amerasinghe C (2014) International Administrative Tribunals. In: Romano C et al. (eds), The Oxford Handbook of International Adjudication. Oxford University Press, Oxford, pp 317-335

Balladore Pallieri G (1969) Le droit interne des organisations internationales, Collected Courses of The Hague Academy of International Law 127:1-36

Bradlow D, Hunter D (eds) (2010) International Financial Institutions and International Law. Kluwer Law International, Alphen aan den Rijn

CEB (2016) Common Principles to Guide the UN System's Support to the Implementation of the 2030 Agenda for Sustainable Development. https://www.unsceb.org/content/ceb-commonprinciples-on-2030-agenda-sustainable (Accessed 3 January 2018)

Coffey P, Riley R (2006) Reform of the International Institutions: The IMF, World Bank and the WTO. Edward Elgar, Cheltenham

Darrow M (2006) Between Light and Shadow: The World Bank, the IMF and International Human Rights Law. Hart, Oxford

Das et al. (2017) Compensation, Diversity and Inclusion at the World Bank Group, World Bank Group Policy Research Working Paper 8058

Dominicé C (2001) Morgan v. World Bank (Ten Years Later). In: Schlemmer-Schulte S (ed), Liber amicorum Ibrahim F. I. Shihata-International Finance and Development Law. Kluwer Law International, The Hague, pp 155-168

Elias O (ed) (2012) The Development and Effectiveness of International Administrative Law: On the Occasion of the Thirtieth Anniversary of the World Bank Administrative Tribunal. Nijhoff, Leiden

Hammerschlag D (1992) Morgan v. International Bank for Reconstruction and Development, Maryland Journal of International Law and Trade 16:279-303 
Hansen P (2007) The World Bank Administrative Tribunal's External Sources of Law: A Retrospective of the Tribunal's First Quarter-Century (1981-2005), The Law and Practice of International Courts and Tribunals: A Practitioners' Journal 6:1-87

Hansen P (2012a) The World Bank Administrative Tribunal's External Sources of Law: The Next Chapter (2006-2010) Part II, The Law and Practice of International Courts and Tribunals: A Practitioners' Journal 11:199-251

Hansen P (2012b) The World Bank Administrative Tribunal's External Sources of Law: The Next Chapter (2006-2010) Part I, The Law and Practice of International Courts and Tribunals: A Practitioners' Journal 11:449-497

Herz S (2010) Rethinking International Financial Institution Immunity. In: Bradlow D, Hunter D (eds), International Financial Institutions and International Law. Kluwer Law International, Alphen aan den Rijn, pp 137-165

ICSC (2013) Standards of Conduct in the International Civil Service. https://icsc.un.org/resources/pdfs/general/standardsE.pdf (Accessed 3 January 2018)

ICSC (2017) Compendium of Decisions and Recommendations. https://www.unicsc.org/compendium/default.asp (Accessed 3 January 2018)

Jenks C (1962) The Proper Law of International Organisations. Stevens, London

Kapur D et al. (1997) The World Bank: Its First Half Century. Brookings Institution Press, Washington DC

Leroy A (2011) Strengthening the Bank's Internal Rule of Law. In: The World Bank Legal Vice Presidency, WB Annual Report FY 2011, pp. 51-66

Marshall K (2008) The World Bank: From Reconstruction to Development to Equity. Routledge, London

Mason E, Asher R (1973) The World Bank since Bretton Woods. Brookings Institution, Washington $\mathrm{DC}$

Martha R (2012) International Financial Institutions and Claims of Private Parties: Immunity Obliges, The World Bank Review, 3:93-131

Okeke E (2016) Annex VI - International Bank for Reconstruction and Development. In: Reinisch A (ed), The Conventions on the Privileges and Immunities of the United Nations and Its Specialized Agencies. Oxford University Press, Oxford, pp 755-776

Philips D (2009) Reforming the World Bank: Twenty Years of Trial - and Error. Cambridge University Press, Cambridge

Reinisch A (ed) (2016) The Conventions on the Privileges and Immunities of the United Nations and Its Specialized Agencies. Oxford University Press, Oxford

Reinisch A, Wurm J (2010) International Financial Institutions before National Courts. In: Bradlow D, Hunter D (eds.), International Financial Institutions and International Law. Kluwer Law International, Alphen aan den Rijn, pp 103-136 
Ruzié D (1999) La sécurité du personnel des Nation Unies recruté sur le plan local, Journal du droit international, 2:435-444

Seatzu F (2015) The Treatment of International Law in the Jurisprudence of the World Bank Administrative Tribunal, The Law and Practice of International Courts and Tribunals: A Practitioners' Journal 14:130-150

Seyersted F (1967) Applicable Law in Relations between Intergovernmental Organizations and Private Parties, Collected Courses of The Hague Academy of International Law 122:427-616

Sheed F (2012) The Scope of the World Bank Administrative Tribunal Remedies: Beyond Individual Relief. In: Elias O (ed), The Development and Effectiveness of International Administrative Law. Nijhoff, Leiden, p 233-240

Shihata I (1991) The World Bank in a Changing World. Nijhoff, Leiden

Shihata I (2000) The World Bank Legal Papers. Nijhoff, Leiden

UN Globe (2015) Mobility Proposals. https://static1.squarespace.com/static/5367af22e4b0915380a1 eb0a/t/54dbe1 fde4b044aeedf41a30/14 23696381616/UN-GLOBE+mobility+proposals+-+2015.pdf (Accessed 8 January 2018)

UNSMS (2017) Security Policy Manual. https://www.un.org/undss/sites/www.un.org.undss/files/docs/security_policy_manual_spm_ebook_as_of_29_nov_2017_0.pdf(Accessed 3 January 2018)

Villalpando S (2016a) The Law of the International Civil Service. In: Cogan J et al. (eds), The Oxford Handbook of International Organizations. Oxford University Press, Oxford, pp 1069-1084

Villalpando S (2016b) International Administrative Tribunals. In: Cogan J et al. (eds), The Oxford Handbook of International Organizations. Oxford University Press, Oxford, pp 1085-1104

World Bank (2009) Code of Conduct "Living Our Values". http://siteresources.worldbank.org/INTETHICS/Resources/World_Bank_Group_Code_Of_Conduct _11_06_09.pdf (Accessed 8 January 2018)

\section{List of cases}

ECtHR, Klausecker v. Germany, 6 January 2015, App. No. 415/07

ECtHR, Perez v. Germany, 6 January 2015, App. No. 15521/08

ECtHR, Waite and Kennedy v. Germany, 18 February 1999, App. No. 26083/94

ICJ, Effects of Awards of Compensation Made by the United Nations Administrative Tribunal, Advisory Opinion, 13 July 1954

ICJ, Interpretation of the Agreement of 25 March 1951 between the WHO and Egypt, Advisory Opinion, 20 December 1980 
IMFAT, A. v. IMF, 12 August 1999, Judgment No. 1999-1, (see Annex YZ, Case 28)

UNDT, Hassouna v. Secretary General of the United Nations, 10 July 2014, Judgement No. UNDT/2014/094 (see Annex YZ, Case 40)

UNDT, Obdeijn v. UN Secretary-General, 10 February 2011, Judgment No. UNDT/2011/032

US Court of Appeal, District of Columbia Circuit, Mendaro v. World Bank, 27 September 1983, 717 F.2d 610

US District Court, District of Columbia, Morgan v. IBRD, 13 September 1990, 752 F. Supp. 492

WBAT, Alrayes v. IFC, 13 November 2015, Decisions No. 520 (see Annex YZ, Case 43)

WBAT, Alrayes v. IFC, 8 April 2016, Decisions No. 529 (see Annex YZ, Case 43)

WBAT, C.L. v. IBRD, 26 September 2014, Decision No. 499

WBAT, de Merode et al. v. the World Bank, 5 June 1981, Decision No. 1 (see Annex YZ, Case 44)

WBAT, E.I. v. IBRD, 25 October 2017, Decision No. 569

WBAT, Mendaro v. IBRD, 4 September 1985, Decision No. 26 (see Annex YZ, Case 45)

WBAT, Sharpston v. IBRD, 23 July 2001, Decision No. 251 (see Annex YZ, Case 46)

WBAT, Tamara Lansky (No. 1 and No. 2) v. IFC and IBRD, 9 December 2009, Decision No. 425 (see Annex YZ, Case 47)

WBAT, Tamara Lansky (No. 3) v. IFC and IBRD, 29 October 2010, Decision No. 442 (see Annex YZ, Case 47)

WBAT, The World Bank Staff Association v. IBRD, IDA, IFC, 27 October 1987, Decision No. 40 